IJOTL TL, Vol. 5, No. 3, September 2020

p ISSN: 2502 2326; e ISSN: 2502 8278

Https://soloclcs.org; Email: ijolt1@gmail.com

Center of Language and Cultural Studies, Surakarta, Indonesia

Mardliyah, Noor. (2020). Team Game Tournament Learning Model

to Improve the Students' Speaking Achievement

IJOTL TL (2020), 5(3), 197 213. DOI: 10.30957/ijot1 t1.v5i1.637.

\title{
Team Game Tournament Learning Model to Improve the Students' Speaking Achievement
}

\author{
Noor Mardliyah \\ Madrasah Tsanawiyah Negeri 2 Kudus \\ Email: mardliyah2@gmail.com
}

\begin{abstract}
This study aims to find out whether the implementation of Team Game Tournament (TGT) can improve students' speaking ability and activity in grade IX-D of MTs Negeri 2 Kudus. This is a classroom action research. This research was carried out in several cycles. Each cycle consists of planning, implementing, observing and reflecting. The variables of this study comprise of student achievement and teacher activity. The results showed the teacher's performance increased according to the criteria on the indicator, which was shown in cycle I was sufficient and cycle II to be good. Student activities during learning are very good, in the first cycle with a percentage of $66.67 \%$ and the second cycle with a percentage of $93.33 \%$. The students' speaking achievement is shown by the average of students' evaluation result in the first cycle (6.85) and the second cycle is 8.63. In the first cycle the students who finished learning were 14 students or $46.67 \%$ and those who did not complete as many as 16 students or $53.33 \%$, and classical learning completeness $46.67 \%$. In cycle II there were 30 students who had finished learning and none of them had finished learning, and classical learning completeness was $100.00 \%$. This means that the results of the second cycle evaluation are better (increased) than the first cycle and need not be continued in the next cycle. The learning model of TGT is relatively high, reaching $81.73 \%$.
\end{abstract}

Keywords: Team Game Tournament, action research, learning model

\section{INTRODUCTION}

Learning is essentially reading, reading texts, reading conditions, reading conditions, reading problems, reading experiences and at the same time finding a way out of the experiences and problems faced. Reading is the main pillar of learning. The teachers are required to have a learning model that can stimulate the enthusiasm of each student to be actively involved in their learning experiences(Gagne, 2011; Widhiastuti \& Fachrurrozie, 2014).

In learning process, the teachers as managers of learning must be able to bring a comfortable and pleasant classroom atmosphere and be able to strive for the formation of student activity in the learning process (de Houwer et al., 2013; Mcclellan, 1982). In fact, there are various problems encountered during the learning process, one of which 
IJOTL TL, Vol. 5, No. 3, September 2020

p ISSN: 2502 2326; e ISSN: 2502 8278

Https://soloclcs.org; Email: ijolt1@gmail.com

Center of Language and Cultural Studies, Surakarta, Indonesia

Mardliyah, Noor. (2020). Team Game Tournament Learning Model

to Improve the Students' Speaking Achievement

IJOTL TL (2020), 5(3), 197 213. DOI: 10.30957/ijotl t1.v5i1.637.

is the lack of active students in the learning process in class, thus making the learning process only oriented towards the teacher.

To produce good quality teaching, a teacher must choose and apply better method. The teacher can certainly explain a material to their students smoothly and understandably by all children. Some of these methods include the enthusiasm of teachers in delivering material and preparation of material to be taught, teachers should prepare material in advance to be taught tomorrow (Sallis, 2014).

One of the problems in teaching English is that in delivering the material to the children, the teachers do not prepare themselves to deliver the material. The opposite condition states that the teacher could not explain the material clearly and clearly, and was difficult for students to understand. The teacher's attitude when delivering material to students, is also important, the teacher must be disciplined, polite, dignified, fair and not discriminate between students who are stupid and smart, the teacher must pay attention and not be indifferent to students, and finally, when the lesson is over, The teacher gives an outline or summary of the material being taught. Teachers also should not be monotonous in teaching, occasionally delivering material by rolling games that can hone vocabulary, such as scrabble, hangman and guess words in English (Bateman, 1981; Richards \& Rodgers, 1999).

Silberman (2006) states that the students are able to understand the material thoroughly if they are supported by the appropriate teaching methods applied by the instructor/lecturer. By knowing the problems in learning English, hopefully the teachers can improve their quality of teaching. And as students should also be active when the teacher explains the material. The teaching and learning model of TGT, developed by Robert Slavin, is a learning technique by combining group learning with team competition, and can be used to enhance learning of various facts, concepts and skills (Silberman, 2006: Slavin, 1985). Learning with this model will stimulate the activeness of students, because in the TGT, there are no students who do not actively voice their opinions, students with the ability of lower groups or groups to work together to solve the problems given in learning(Setiawan, 2017).

TGT is more concerned with group success than individual success. The rewards obtained by the group are largely determined by the successful mastery of the material for each group member. TGT uses academic game tournaments. In this tournament students compete to represent their team with other team members who are equal in academic performance(Jolliffe, n.d.; Zhayida et al., 2015).

TGT is one type of cooperative learning. Activities in TGT are almost the same as STAD (Student Team Achievement Divisions). Broadly speaking, TGT in learning is a STAD activity that is added to the game. So, to increase the score obtained by the team / group is given again with a game. Thus, the teacher must prepare a game that is played by students after the quiz (Slavin, 1985:24; Jolliffe, n.d.).

Of the cooperative learning types, TGT still exists among others. TGT is expected to instill student sportsmanship and arouse the students' motivation to try better than other members. In the tournament, this model can also form students to be ordinary and brave to compete, so the students always try to be in a superior position 
IJOTL TL, Vol. 5, No. 3, September 2020

p ISSN: 2502 2326; e ISSN: 2502 8278

Https://soloclcs.org; Email: ijolt1@gmail.com

Center of Language and Cultural Studies, Surakarta, Indonesia

Mardliyah, Noor. (2020). Team Game Tournament Learning Model

to Improve the Students' Speaking Achievement

IJOTL TL (2020), 5(3), 197 213. DOI: 10.30957/ijot1 t1.v5i1.637.

because they have high competitiveness(July \& Bennett, 2009; Johnson \& Johnson, 1991).

The real conditions in the field show that student achievement tends to be static and stagnant and even decline. This problem occurs because there is no motivation to learn. As a result of the application monotonous learning models, there is no variation in the learning processno gain for the students. The students' learning achievement did not increaseespecially in English subject in grade IX-D of MTs Negeri 2 Kudusin academic year of $2019 / 2020$. For this reason, it is necessary to apply a learning model that involves a lot of active students so that they can improve student enthusiasm for learning. One learning model that can actively involve students is the TGT. This study aims tofind out whether the implementation of TGT can increase thestudents'speaking ability and activity.

To carry out the above learning also made learning tools, which include teaching plans using TGT, an observation sheet that is to find out the activities and collaboration of students in the process of implementing the learning process. The learning achievement test is to find out the competence of students in working on evaluation questions and the level of success can be seen at the end of each cycle. If the results obtained are not satisfactory, then a further cycle is held, that is cycle II and so on.

\section{METHODS}

The design of this research is action research and was carried out in several cycles(Tomal, 2003). Each cycle consists of planning, implementing, observing and reflecting. The results of the study focused on students' ability to work on learning evaluation questions so that learning achievement and learning completeness can be achieved (Mcniff, 2002; Somekh, 2006). The flow in this classroom action research consists of 4 series of activities carried out in a repetitive cycle. Four main activities in each cycle are planning, action, observation and reflection. In accordance with the researchers' ideas, this class action research is designed to be carried out in several cycles until it reaches the expected results(Hanifah \& Firman, 2019; Burns, 2010).

TGT consists of five components, namely: (1) class presentations, to explain the material in outline and explain the learning techniques to be implemented, (2) Teams or Groups, consisting of 3 to 6 students in heterogeneous groups regardless of ethnic or national intelligence, (3) games, to test the knowledge students get after class presentations and group learning, (4) tournaments during games, and (5) team awards, in the form of certificates or other forms of appreciation(Slavin, 1985; Setiawan, 2017).After the tournament is finished and assessed, the teacher rearranges the student's position at each tournament table. Unless the winner is at the "highest" table, the winner at each table is "raised" or moved one level to a higher table. And those who score the lowest on each tournament table other than the one on the "lowest" table are "downgraded" one level to the lower table. In the end they will experience an increase or decrease so they will arrive at a table that matches their performance.

The subjects of this study are 28 students of grade IX-D of MTs Negeri 2 Kudus. The study was carried out in 3 (three) months, starting in July until September 2019, starting from the initial observation, planning, the implementation of the first cycle, the 
implementation of the second cycle, and the preparation of reports. The analysis of students' activity data in learning process is done by evaluating the results of instruments using descriptive techniques through percentages $(\%)=$.Data analysis regarding learning achievement was taken from the cognitive abilities of students in solving problems analyzed by calculating the average value of classical mastery learning with formulas. The analysis of student interest data is carried out to determine student responses in learning through the TGT with answer assessment criteria. The indicators in improving the students' learning are in cognitive abilities by TGT model. This research stands for a hypothesis. The action research hypothesis is a temporary answer to the problem to be studied (Arikunto, 1994:9; Hadi, 1990: 23).

\section{RESULTS}

\subsection{Preparation}

In conducting research it is necessary to hold a research preparation so that the results achieved are truly optimal. Several things that researchers need to do before conducting research are as follows:

a) Conducting observations to identify problems through interviews with fellow teachers.

b) The researcher asks the principal for permission to conduct research.

c) Determine the class chosen as the subject of research based on the consideration of fellow teachers.

d) Making research instruments in the form of lesson plans, teacher observation sheets, student activity observation sheets, worksheets and evaluation questions.

e) Develop a student questionnaire of interest in TGT.

\subsection{Implementation}

The implementation of study was designed in several cycles, each cycle consisting of four stages, namely planning, action, observation and reflection. The cycle is considered sufficient when it reaches the expected results.

\section{Cycle I}

Planning

a) The researcher plans the TGT by making a learning plan.

b) Prepare worksheets for students that will be used to solve problems.

c) Prepare an observation sheet, including teacher activity observation sheets and student activity observation sheets.

d) Researchers (teachers) prepare competency test questions. Competency tests given to these students are evaluation questions.

\section{Implementation}

a) The researcher/teacher explains the material according to the teaching plan and refer to learning using the TGT accordance with the steps in the worksheet.

b) The researchers divide students into groups.

c) The researchers/teachers give questions to each group. 
d) The researcher/teacher distributes worksheets in the form of steps in solving problems/evaluation questions.

e) The students conduct group discussions to solve the problem / evaluation questions.

f) The researchers/teachers walk around guiding, supervising and helping students who have difficulty solving problems / evaluation questions.

g) The researchers/teachers motivate students to conduct discussions in groups to find as much information as possible in solving the problems given.

h) The researcher/teacher invites one group representative to come forward and present their work in front of the class.

i) Other students pay attention and may ask if there is anything unclear.

j) The researchers/teachers evaluate the results of their work.

k) The researchers/teachers provide competency test / evaluation tests.

\section{Observation}

From the observations on the students' activities in groups at the first cycle, the activeness of students in the first cycle in participating in teaching and learning activities using TGT still low, obtained a score of 20 from a maximum score of 30 with a percentage of $66.67 \%$. The results of observations on the performance of The researchers/teachers in the first cycle obtained a score of 22 or $56.41 \%$ of the maximum score of 39 with learning criteria "sufficient" in delivering the material, but the beginning of the lesson was less able to motivate students so that the learning process of student activity was still lacking.

\section{Reflection}

After observing the learning actions, further reflection is taken of the actions that have been carried out. In the activities of first cycle, the results of reflection are as follows:

During the discussion the teacher / researcher monitored the work of each group, but it was still not optimal and the guidance carried out by the teacher towards the group was not evenly distributed, so some groups were unable to solve problems / problems properly. Individual guidance is also lacking in attention, so there are students who are not involved in solving problems / problems. If done more optimally, the teacher will know the characteristics and weaknesses of students, so students can understand the learning material at that time.

a) Teachers / researchers in fostering student learning motivation in order to foster student interest in the process ofTGTare still less than optimal.

b) Student attention to teacher explanation is still low.

c) In working on questions students are still less active.

d) During group work students are less able to interact with others.

e) The students are still reluctant to make presentations. Students still point at each other to make a presentation in front of the class.

f) The attitude of students in paying attention to the presentation and opinions of friends is still lacking.

g) Quiet class in learning is still not good or there are still many who are busy alone. 


\section{Cycle II}

Planning

Based on cycle I, researchers and teachers plan the TGT on the subject matter by making a learning plan.

a) Arrange worksheets for students. Worksheets given to students are used to solve problems. Compile observation sheets that will be used by researchers to observe student and teacher communication activities in learning using the TGT.

b) Develop competency test / evaluation questions.

\section{Implementation}

a) Researcher / Teacher explain the material according to the teaching plan and refer to learning using the learning model in TGT accordance with the steps in the worksheet.

b) The researchers/teachers divide students into groups.

c) The researchers/teachers give questions to each group.

d) The researchers/teachers distribute worksheets in the form of steps in solving problems / problems.

e) Students solve problems in groups.

f) The researchers/teachers walk around guiding, supervising and helping students who have difficulty solving problems / problems.

g) The researchers/teachers motivate students to have discussions in groups to find as much information as possible in solving the problems given.

h) The researchers/teachers invite one of the group representatives to come forward and present their work in front of the class.

i) Other students pay attention and may ask if there is anything unclear.

j) The researchers/teachers evaluate the results of student work.

k) The researchers/teachers provide competency test questions.

\section{Observation}

The activeness of students in the second cycle in participating in teaching and learning activities using the TGT can be said that the activeness of "high", obtained a score of 28 or $93.33 \%$ of the maximum score of 30 . The results of observations on the performance of The researchers/teachers in the second cycle obtained a score of 38 or $97.44 \%$ of the maximum score of 39 with the criteria of "good".

\section{Reflection}

a) During the discussion, the teacher/researcher monitors the work of each group. It will support much and the guidance carried out the teacher towards the group is evenly distributed, so that several groups can solve the problem/problem well. Individual guidance has been considered, so that all students are involved in problem solving. 
b) The teacher/researcher in fostering student learning motivation in order to foster student interest in the process of learning models Team Game Tournament (TGT) is optimal.

c) Student attention to teacher explanation has increased.

d) In working on problems students are active.

e) During group work students can interact with others.

f) Students no longer feel ashamed to make a presentation.

g) Students 'attitudes in paying attention to presentations and peers' opinions have improved.

h) Class peace in learning is good.

\section{DISCUSSION}

\subsection{Cycle I}

From the observations made on the activities of students in groups in the first cycle, the results are obtained as follows:

Table 1 Student Activity in Cycle I Groups

\begin{tabular}{|c|c|c|c|c|c|}
\hline \multicolumn{6}{|c|}{ STUDENT ACTIVITY TABLE IN CYCLE GROUP I } \\
\hline No & & Student Activity & Score & $\%$ & Note \\
\hline 1 & A. & $\begin{array}{l}\text { Paying attention on teachers' } \\
\text { explanation }\end{array}$ & 63 & $53 \%$ & Moderate \\
\hline 2 & B. & Working in group & 70 & $58 \%$ & Moderate \\
\hline 3 & C. & $\begin{array}{l}\text { Askingamongstudents and } \\
\text { teachers }\end{array}$ & 71 & $59 \%$ & Moderate \\
\hline 4 & D. & Activeness to answer the question & 73 & $61 \%$ & Moderate \\
\hline 5 & E. & Ability of students' achievement & 82 & $68 \%$ & Moderate \\
\hline
\end{tabular}

The activeness of students in the first cycle in participating in teaching and learning activities using TGT still low, obtained a score of 20 from a maximum score of 30 with a percentage of $66.67 \%$. The results of observations on the performance of The researchers/teachers in the first cycle obtained a score of 22 or $56.41 \%$ of the maximum score of 39 with learning criteria "sufficient" in delivering the material, but the beginning of the lesson was less able to motivate students so that the learning process of student activity was still lacking.

The students' group activity in cycle I can be seen in chart 1 below:

Chart 1 students' group activity 
IJOTL TL, Vol. 5, No. 3, September 2020

p ISSN: 2502 2326; e ISSN: 2502 8278

Https://soloclcs.org; Email: ijolt1@gmail.com

Center of Language and Cultural Studies, Surakarta, Indonesia

Mardliyah, Noor. (2020). Team Game Tournament Learning Model

to Improve the Students' Speaking Achievement

IJOTL TL (2020), 5(3), 197 213. DOI: 10.30957/ijot1 tl.v5i1.637.

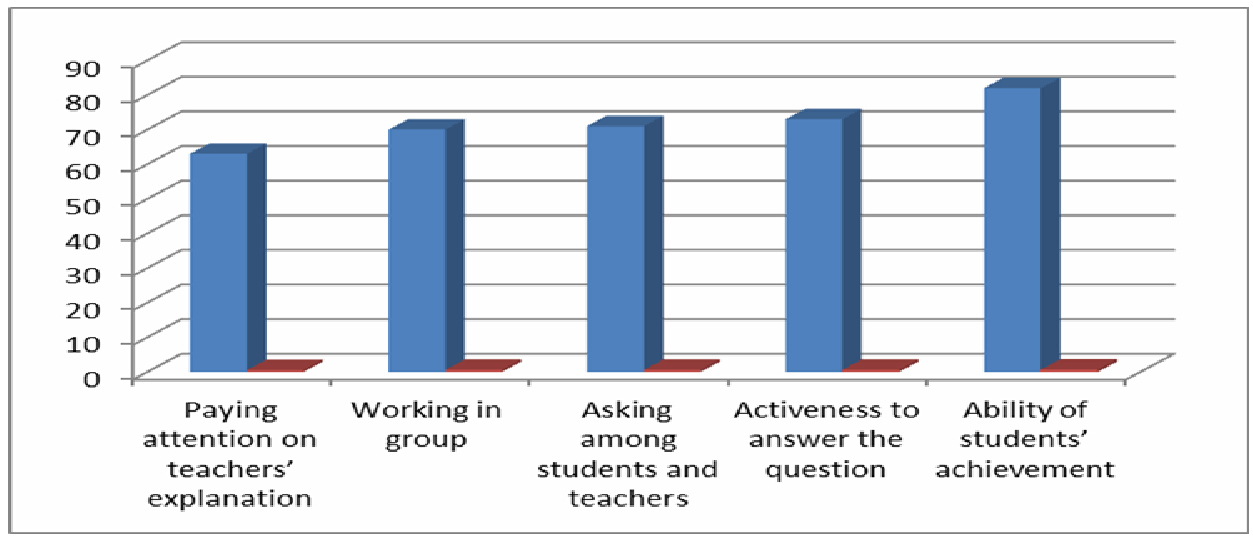

Observation of the results of the competency test/evaluation results of first cycle obtained the following results:

Table 2 Evaluation Results of the Cycle I

\begin{tabular}{c|l|c|c}
\hline \multicolumn{4}{|c}{ EVALUATION TABLE OF CYCLE I } \\
\hline No & \multicolumn{1}{|c}{ Evaluation Result } & Score & $\%$ \\
\hline 1 & Average & 6,85 & $68,53 \%$ \\
\hline 2 & Highest Value & 8,80 & \\
\hline 3 & Lowest Value & 4,80 & \\
\hline 4 & Number of students who completed & 14 & $46,67 \%$ \\
\hline 5 & $\begin{array}{l}\text { Number of students who did not } \\
\text { complete }\end{array}$ & 16 & $53,33 \%$ \\
\hline 6 & Classical completeness & 15 & $46,67 \%$ \\
\hline
\end{tabular}

Chart 2 Evaluation Results of the Cycle I

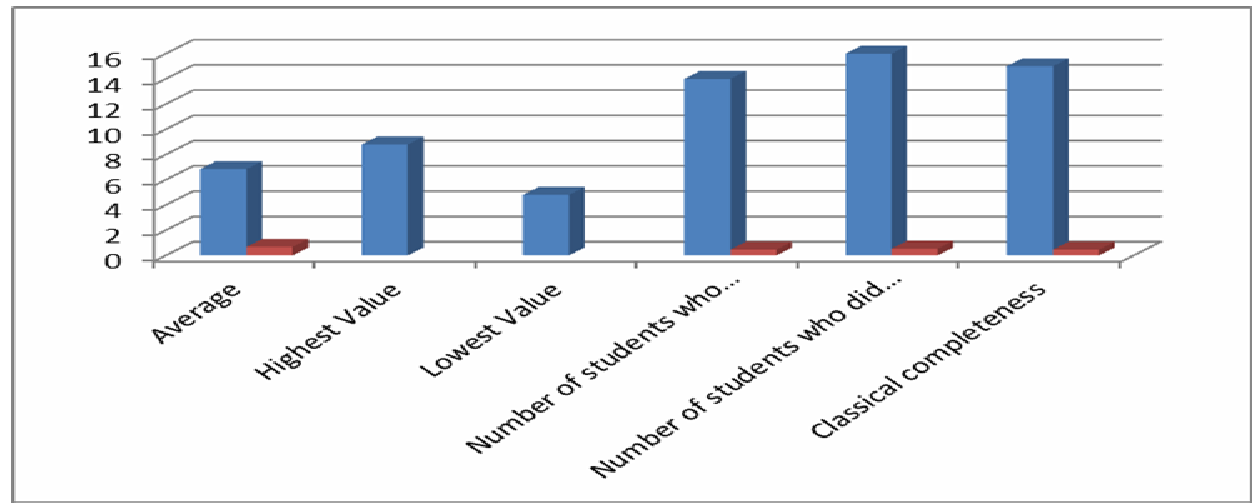

Because the percentage of mastery learning classical has only reached $46.67 \%$, it has not met the expected results of the mastery/success indicator. The individual competency test results can be seen in the following table: 


\section{Reflection}

After observing the learning actions, further reflection is taken of the actions that have been carried out. In the activities of first cycle, the results of reflection are as follows:

During the discussion the teacher / researcher monitored the work of each group, but it was still not optimal and the guidance carried out by the teacher towards the group was not evenly distributed, so some groups were unable to solve problems / problems properly. Individual guidance is also lacking in attention, so there are students who are not involved in solving problems / problems. If done more optimally, the teacher will know the characteristics and weaknesses of students, so students can understand the learning material at that time.

h) Teachers / researchers in fostering student learning motivation in order to foster student interest in the process ofTGTare still less than optimal.

i) Student attention to teacher explanation is still low.

j) In working on questions students are still less active.

k) During group work students are less able to interact with others.

1) The students are still reluctant to make presentations. Students still point at each other to make a presentation in front of the class.

$\mathrm{m})$ The attitude of students in paying attention to the presentation and opinions of friends is still lacking.

n) Quiet class in learning is still not good or there are still many who are busy alone.

The results of the competency test in the first cycle obtained the highest value of 8.8; lowest value of 4.8; average value of 6.85 ; students who have finished learning as many as 14 students or $46.67 \%$; and students who did not complete the study as many as 16 students or $53.33 \%$; and classical learning completeness obtained $46.67 \%$. From the results of the first cycle, it means that the learning process has not been successful or has not met the classical learning completeness criteria. Therefore, it is necessary to improve the actions in cycle II.

\subsection{Cycle II \\ Planning}

Based on cycle I, researchers and teachers plan the TGT on the subject matter by making a learning plan.

c) Arrange worksheets for students. Worksheets given to students are used to solve problems. Compile observation sheets that will be used by researchers to observe student and teacher communication activities in learning using the TGT.

d) Develop competency test / evaluation questions.

\section{Implementation}

1) Researcher / Teacher explain the material according to the teaching plan and refer to learning using the learning model in TGT accordance with the steps in the worksheet.

m) The researchers/teachers divide students into groups. 
n) The researchers/teachers give questions to each group.

o) The researchers/teachers distribute worksheets in the form of steps in solving problems / problems.

p) Students solve problems in groups.

q) The researchers/teachers walk around guiding, supervising and helping students who have difficulty solving problems / problems.

r) The researchers/teachers motivate students to have discussions in groups to find as much information as possible in solving the problems given.

s) The researchers/teachers invite one of the group representatives to come forward and present their work in front of the class.

t) Other students pay attention and may ask if there is anything unclear.

u) The researchers/teachers evaluate the results of student work.

v) The researchers/teachers provide competency test questions.

\section{Observation}

The activities of students in groups in cycle II are:

Table 3 Students' activity in Group Cycle I

\begin{tabular}{c|c|c|c|c|c}
\hline \multicolumn{5}{c}{ STUDENTS' ACTIVITY GROUPIN CYCLE II } \\
\hline No & \multicolumn{1}{|c}{ Students' Activity } & Score & $\%$ & Remark \\
\hline 1 & A. & $\begin{array}{l}\text { Paying attention to teacher's } \\
\text { explanation }\end{array}$ & 112 & $93 \%$ & High \\
\hline 2 & B. & Collaboration in groups & 114 & $95 \%$ & High \\
\hline & C. & $\begin{array}{l}\text { Asking between students and } \\
\text { teachers }\end{array}$ & 107 & $89 \%$ & High \\
\hline 4 & D. & Activity Solving problems & 106 & $88 \%$ & High \\
\hline 5 & E. & Students' presentation skills & 107 & $89 \%$ & High \\
\hline
\end{tabular}

The activeness of students in the second cycle in participating in teaching and learning activities using the TGT can be said that the activeness of "high", obtained a score of 28 or $93.33 \%$ of the maximum score of 30 . The results of observations on the performance of The researchers/teachers in the second cycle obtained a score of 38 or $97.44 \%$ of the maximum score of 39 with the criteria of "good".

The students' activity in Group Cycle I can be seen in chart 3 below: 
IJOTL TL, Vol. 5, No. 3, September 2020

p ISSN: 2502 2326; e ISSN: 2502 8278

Https://soloclcs.org; Email: ijolt1@gmail.com

Center of Language and Cultural Studies, Surakarta, Indonesia

Mardliyah, Noor. (2020). Team Game Tournament Learning Model

to Improve the Students' Speaking Achievement

IJOTL TL (2020), 5(3), 197 213. DOI: 10.30957/ijot1 tl.v5i1.637.

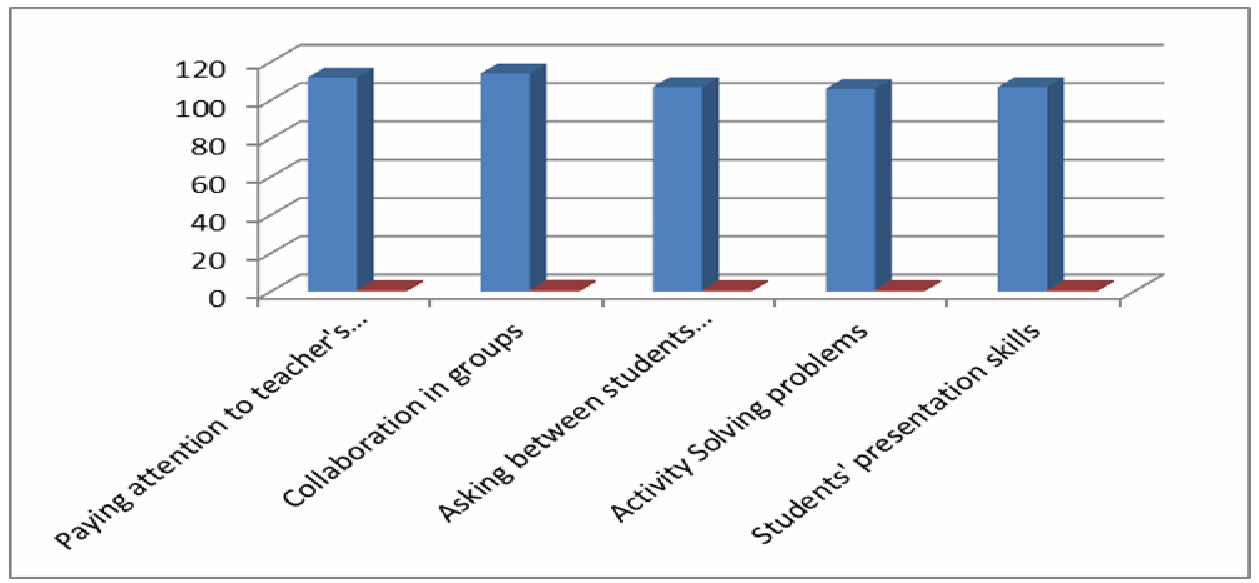

The observation of the results of the cycle II competency test results are as follows:

Table 4 Results of the Cycle II Evaluation

\begin{tabular}{c|l|c|c}
\hline \multicolumn{4}{|c}{ EVALUATION TABLE OF CYCLE II } \\
\hline No & \multicolumn{1}{|c}{ Evaluation Result } & Score & $\%$ \\
\hline 1 & Average & 8,63 & $86,27 \%$ \\
\hline 2 & Highest Score & 9,20 & \\
\hline 3 & Lowest score of & 7,60 & \\
\hline 4 & Number of students who completed & 30 & $100 \%$ \\
\hline 5 & $\begin{array}{l}\text { Number of students who did not } \\
\text { complete }\end{array}$ & 0 & $0 \%$ \\
\hline & Classical completeness & & $100 \%$ \\
\hline
\end{tabular}

The results of Evaluation in cycle II can be seen in chart 4 below:

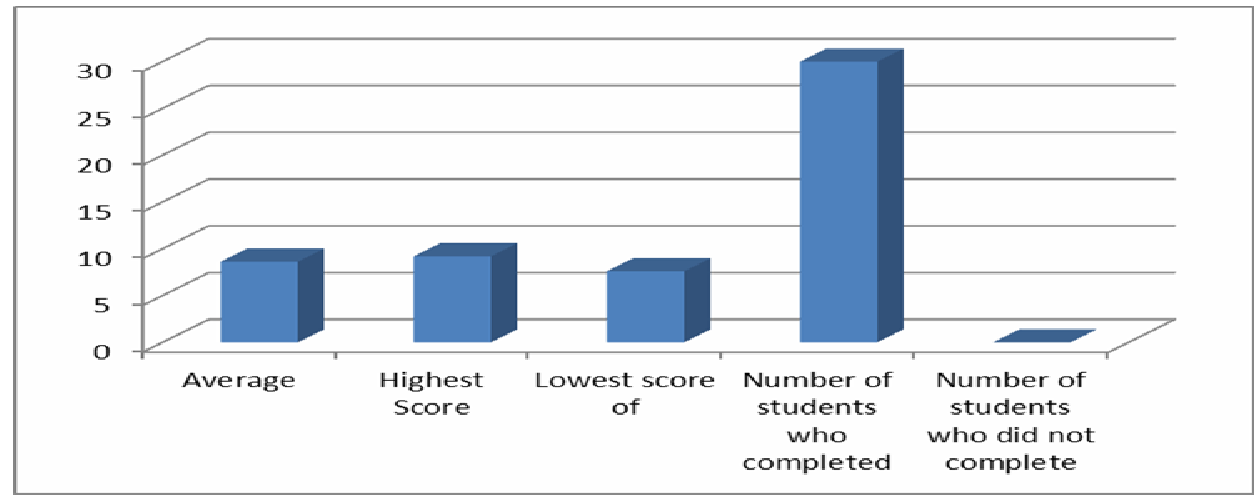

Because classical completeness has reached $100.00 \%$ (this is in accordance with the criteria to be achieved and has met the indicators of mastery learning. 


\section{Reflection}

i) During the discussion, the teacher/researcher monitors the work of each group.

It will support much and the guidance carried out the teacher towards the group is evenly distributed, so that several groups can solve the problem/problem well. Individual guidance has been considered, so that all students are involved in problem solving.

j) The teacher/researcher in fostering student learning motivation in order to foster student interest in the process of learning models Team Game Tournament (TGT) is optimal.

k) Student attention to teacher explanation has increased.

1) In working on problems students are active.

m) During group work students can interact with others.

n) Students no longer feel ashamed to make a presentation.

o) Students 'attitudes in paying attention to presentations and peers' opinions have improved.

p) Class peace in learning is good.

The results of the second cycle data processing can be seen that the activeness of students can be categorized as high, obtained a score of 28 or $93.33 \%$ of the maximum score of 30 and has met the established indicators of success. This increase is due to the ability of teachers to motivate and foster interaction between students better than in cycle I. While the performance of the teacher in cycle II obtained a score of 38 or $97.44 \%$ of the maximum score of 39 . From the results of the student competency test in cycle II obtained the highest value 9,20; lowest value of 7.60; and an average value of 8.63. There are 30 or $100 \%$ students who have finished learning and none of them have finished. This shows an increase compared to the first cycle, thus there is no need for a third cycle.

\subsection{Comparison of Cycle I and Cycle II}

Based on the description above, it can be made a comparison table of cycle I and cycle II as follows:

1) Comparison of Student Activities in Groups

Table 5 Comparison of Student Activities in Groups

\begin{tabular}{c|l|l|c|c|c}
\hline \multicolumn{5}{c}{ TABLES OF STUDENT ACTIVITIES IN GROUP } \\
\hline No & & \multicolumn{1}{|c}{ Student Activity } & Cycle I & Cycle II & Remarks \\
\hline & & $\begin{array}{l}\text { Pay attention to teacher } \\
\text { explanations }\end{array}$ & $53 \%$ & $93,33 \%$ & Increase \\
\hline 2 & B. & Collaboration in groups & $58 \%$ & $95,00 \%$ & Increase \\
\hline 3 & C. & Ask between students and & $59 \%$ & $89,17 \%$ & Increase \\
\hline
\end{tabular}


IJOTL TL, Vol. 5, No. 3, September 2020

p ISSN: 2502 2326; e ISSN: 2502 8278

Https://soloclcs.org; Email: ijolt1@gmail.com

Center of Language and Cultural Studies, Surakarta, Indonesia

Mardliyah, Noor. (2020). Team Game Tournament Learning Model

to Improve the Students' Speaking Achievement

IJOTL TL (2020), 5(3), 197 213. DOI: 10.30957/ijot1 tl.v5i1.637.

\begin{tabular}{c|c|l|c|c|c}
\hline & & teachers & & & \\
\hline 4 & D. & Activity Solving problems & $61 \%$ & $88,33 \%$ & Increase \\
\hline & & & & & \\
5 & E. & Students' presentation ability & $68 \%$ & $89,17 \%$ & Increase \\
\hline
\end{tabular}

The comparison of student activities in groups can be seen in chart 5 below

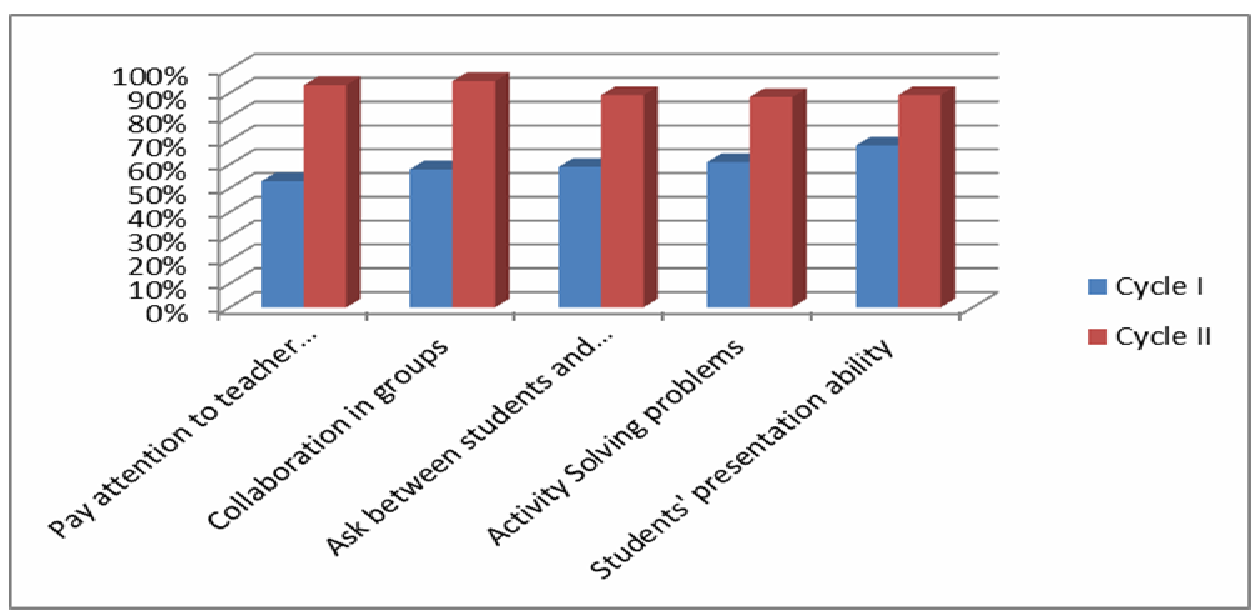

2) Cumulative Comparison

Table 6 Comparison of Cycle I and Cycle II

CUMULATIVE TABLE COMPARISON OF CYCLE I AND

CYCLE II

\begin{tabular}{c|l|c|c}
\hline No & \multicolumn{1}{|c|}{ Indicator } & Cycle I & Cycle II \\
\hline 1 & Student activeness & $67 \%$ & $93 \%$ \\
\hline 2 & Activation in groups & $60 \%$ & $91 \%$ \\
\hline 3 & Student average score & $69 \%$ & $86 \%$ \\
\hline 4 & Students completeness & $47 \%$ & $100 \%$ \\
\hline 5 & Students are incomplete & $53 \%$ & $0 \%$ \\
\hline 6 & Classical completeness & $47 \%$ & $100 \%$ \\
\hline 7 & Teacher performance & $56 \%$ & $97 \%$ \\
\hline 8 & Student interest & \multicolumn{2}{c}{$81,73 \%$} \\
\hline
\end{tabular}

The comparison of Cycle I and Cycle II can be seen in chart 6 below: 
IJOTL TL, Vol. 5, No. 3, September 2020

p ISSN: 2502 2326; e ISSN: 2502 8278

Https://soloclcs.org; Email: ijolt1@gmail.com

Center of Language and Cultural Studies, Surakarta, Indonesia

Mardliyah, Noor. (2020). Team Game Tournament Learning Model

to Improve the Students' Speaking Achievement

IJOTL TL (2020), 5(3), 197 213. DOI: 10.30957/ijot1 t1.v5i1.637.

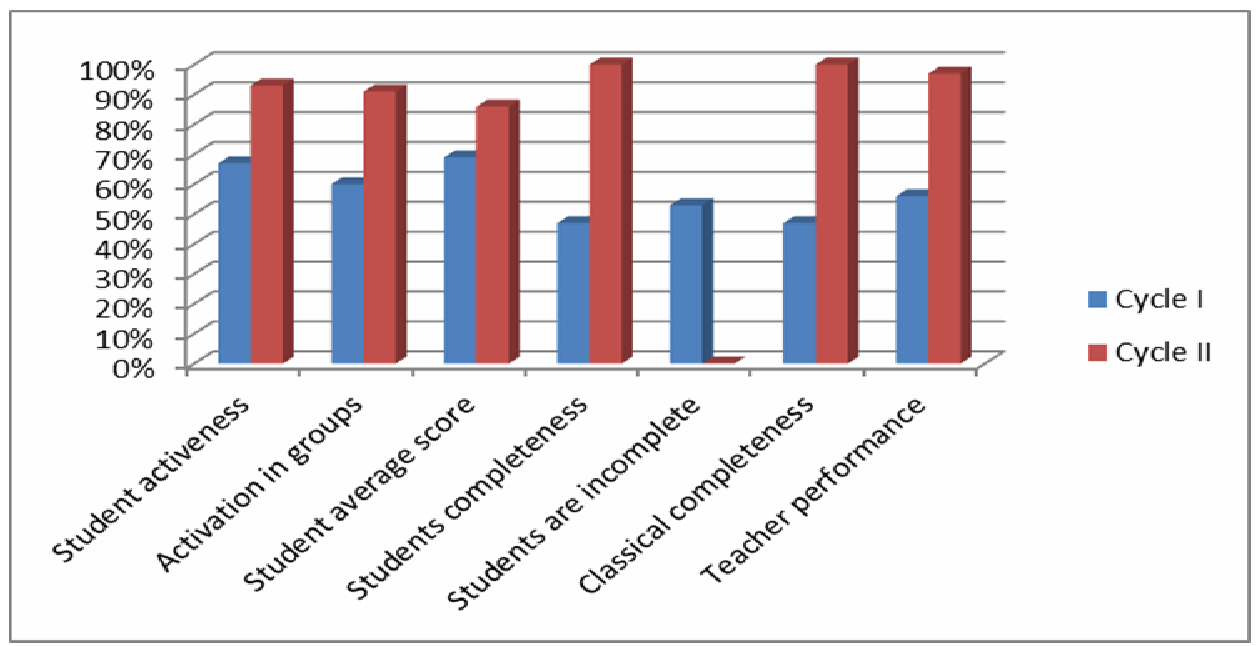

The discussion of research results is based on observations and continued with reflections on cycle I and cycle II. The first cycle, based on the observations by the teacher, showed that the teacher's performance was quite good. Can be seen on the observation sheet of teacher performance in the first cycle shows the score obtained is 22 or $56.41 \%$ of the maximum score of 39 while in the second cycle shows that the teacher's performance is good. It can be seen on the teacher observation sheet cycle II, which shows the score obtained is 38 or $97.44 \%$ of the maximum score of 39 , which shows that the teacher's performance has increased in cycle II compared to cycle I.

Observations on student activity scores obtained from the sheet observation of the activities of students in the first cycle, which is 20 or $66.67 \%$ of the maximum score of 30. This shows that the activity of students classified as low still does not meet the expected criteria, with a minimum percentage of between $60 \%-75 \%$; while in cycle II shows that student activity is high. It can be seen on the observation sheet of the activities of the second cycle students, which shows the score obtained is 28 or $93.33 \%$ of the maximum score of 30 , which means it meets the expected criteria. This shows that student activity has increased in cycle II compared to cycle I.

The results of observations of the discussion of each group in working on the student worksheets have been said to be good. This is indicated by the average value in the first cycle reaching 59.8\%; and in the second cycle increased to $91.0 \%$; This increase occurs because in the second cycle the level of activity and cooperation in the group is higher so that they are able to solve the problems given.

Observations on the results of the evaluation in the first cycle can be seen in the results of the evaluation of the competency test of the first cycle, which shows the ability of students to solve problems, which is obtained an average score of 6.85 , the highest score of 8.8 and the lowest score of 4.8. Students who completed the study were 14 students or $46.67 \%$ and those who did not complete as many as 16 students or $53.33 \%$. This still does not meet the expected criteria, namely classical learning completeness must reach a percentage of $75 \%$. While the results of the evaluation of students in the second cycle can be seen in the results of the evaluation of the second 
IJOTL TL, Vol. 5, No. 3, September 2020

p ISSN: 2502 2326; e ISSN: 2502 8278

Https://soloclcs.org; Email: ijolt1@gmail.com

Center of Language and Cultural Studies, Surakarta, Indonesia

Mardliyah, Noor. (2020). Team Game Tournament Learning Model

to Improve the Students' Speaking Achievement

IJOTL TL (2020), 5(3), 197 213. DOI: 10.30957/ijotl t1.v5i1.637.

cycle, which shows the ability of students to solve the problem is obtained an average score of 8.63, the highest score of 9.2 and the lowest score of 7.6. There were 30 students who completed the study or $100.00 \%$ and none of them had finished. This shows meeting the expected criteria and student learning outcomes have increased in cycle II compared to cycle I.

The results of observation of student activity in the group in the first cycle reached $59.8 \%$ and in the second cycle increased to $91.0 \%$. The results of the student response questionnaire showed that most students liked TGTlearning model, with a percentage of $81.73 \%$, or the criteria "high". Rusman (2011:219) conducted research on TGTlearning model whose results showed that cooperative interactions had various positive effects on children's development. Thus, it can be said that TGTlearning model can improve student achievement, so that this learning model can be a solution for teachers to improve student learning achievement.

\section{CONCLUSION}

This study reveals that TGT has successful to increase learning ability of the students of MTK. The elaboration indicates that (1) There is an increase in English learning achievement, after the application of TGT, this is shown from the results of the evaluation in the second cycle is better (improved) and is in accordance with the established indicators, compared with the results of the evaluation in the first cycle, (2) There was an increase in student activity in the TGT, this was indicated by student activity in cycle II being better (increasing) compared to student activity in cycle I., and (3) Student responses to the implementation of TGT, shows a very good response (high category).

Based on the results of action research, the researchers recommend that: (1) learning requires approaches and strategies that are appropriate to the material and conditions of students, (2) TGT should be applied by teachers, because with this learning can increase student creativity and activity, can make students motivated to study hard, and can improve student learning achievement, (3) in TGT, the teacher as a facilitator should encourage students to be more active and motivated in learning, and the teacher should be more patient and cooperative in learning, especially in dealing with students who are lacking and difficult to accept lessons, and the teacher must be very clever in managing the class.

\section{REFERENCES}

Bateman, B. (1981). Reviews: The Cambridge Guide to Second Language Teacher Education. The Modern Language Journal, 65(2), 203-240. https://doi.org/10.1111/j.1540-4781.1981.tb00975.x

Burns, A. (2010). Doing Action Research in English Language Teaching A Guide for Practitioners ESL amp Applied Linguistics Professional Series.

de Houwer, J., Barnes-Holmes, D., \& Moors, A. (2013). What is learning? On the nature and merits of a functional definition of learning. Psychonomic Bulletin and 
IJOTL TL, Vol. 5, No. 3, September 2020

p ISSN: 2502 2326; e ISSN: 2502 8278

Https://soloclcs.org; Email: 1jolt1@gmail.com

Center of Language and Cultural Studies, Surakarta, Indonesia

Mardliyah, Noor. (2020). Team Game Tournament Learning Model

to Improve the Students' Speaking Achievement

IJOTL TL (2020), 5(3), 197 213. DOI: 10.30957/ijot1 tl.v5i1.637.

Review, 20(4), 631-642. https://doi.org/10.3758/s13423-013-0386-3

Gagne, R. M. (2011). The Conditions of Learning. In Alain Badiou: Key Concepts (2nd ed.). HOLT, RINEHART and WINSTON, Inc.

https://doi.org/10.1017/UPO9781844654703.005

Hanifah, \& Firman. (2019). Model Pembelajaran Teams Games Tournaments Dan Motivasi Belajar Peserta Didik. Jurusan Pendidikan Dasar Dan Bimbingan Dan Konseling Fakultas Ilmu Pendidikan UNP, January.

Johnson, D. W., \& Johnson, R. T. (1991). Cooperative learning and classroom and school climate. Educational Environments, 55-74.

Jolliffe, W. (n.d.). Cooperative Learning in the Classroom Putting it into Practice.

July, O., \& Bennett, D. (2009). What is cooperative learning? ASHE-ERIC Higher Education Report, 20(4), 1-13. https://doi.org/10.1002/aehe.3640200405

Mcclellan, J. E. (1982). Concept of Learning: Once More with (Logical) Expression. 51, $87-116$.

Mcniff, J. (2002). Action Research: Principles and Practice.

Richards, J. C., \& Rodgers, T. S. (1999). Approaches and Methods in Language Teaching. In Cambridge Language Teaching Library (1st ed., Vol. 21, Issue 1). Cambridge University Press. https://doi.org/10.1037/014836

Sallis, E. (2014). Total quality management in education: Third edition. In Total Quality Management in Education: Third Edition. https://doi.org/10.4324/9780203417010

Setiawan, M. A. (2017). Penerapan Metode Pembelajaran Team Game Tournament (TGT) untuk Meningkatkan Keaktifan dan Hasil Belajar pada Kompetensi Alat Ukur pada Program Keahlian Teknik Kendaraan Ringan SMK negeri 1 Sedayu Bantul (Vol. 7, Issue 1). UNIVERSITAS NEGERI YOGYAKARTA.

Slavin, R. E. et al. (1985). Learning to Cooperate, Cooperating to Learn. Plenum Press. https://doi.org/10.1007/978-1-4899-3650-9

Somekh, B. (2006). Action Research: A Methodology for Change and Development. Open University Press.

Tomal, D. R. (2003). Action Research for Educators. In Scarecrow Education Book (1st ed., Vol. 1). Scarecrow Press Inc. https://doi.org/10.1017/CBO9781107415324.004

Widhiastuti, R., \& Fachrurrozie. (2014). Teams Games Tournament (Tgt) Sebagai Metode Untuk Meningkatkan Keaktifan Dan Kemampuan Belajar. Dinamika Pendidikan, 9(1), 48-56. https://doi.org/10.15294/dp.v9i1.3355

Zhayida, S., Burgess, S., Kuang, Y., \& Åström, K. (2015). TOA-Based Self-Calibration of Dual-Microphone Array. IEEE Journal on Selected Topics in Signal Processing, 9(5), 791-801. https://doi.org/10.1109/JSTSP.2015.2417117 